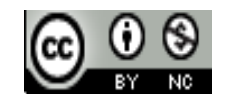

Journal of Education, Teaching, and Learning is licensed under

A Creative Commons Attribution-Non Commercial 4.0 International License.

\title{
INTERNAL QUALITY ASSURANCE SYSTEM (CASE Study OF Model School in State Junior High School SAMbaS 1 (SMPN 1 SAMBAS))
}

\author{
Sri Kurnia, Sukmawati, Muhammad Chiar \\ Universitas Tanjungpura, Pontianak, Indonesia \\ E-mail: srikurnia031@gmail.com
}

\begin{abstract}
The model school is considered to be a great school, even though in reality, the word "model" in the model school is the system, namely theInternal quality assurance system (SPMI) being modeled at the school. The purpose of this study is to describe the Internal Quality Assurance System (case study at the SMPN 1 Sambas. Research conducted by using a qualitative approach with a type of case study research. The stages in this study consist of the stages of preparation, implementation, and reporting. Based on the research that has been done, the following results are obtained. (1) All components in implementing the School's Internal Quality Assurance System Model at SMPN 1 Sambas have been fulfilled by the Head of SMPN 1 Sambas with an average score of 84.34 from a maximum/100 score ; (2) In the process of the School's Internal Quality Assurance System the model in SMPN 1 Sambas has gone through the stages of planning, implementation and supervision in accordance with the provisions and carried out appropriately; (3) Output of the School's Internal Quality Assurance System in SMPN 1 Sambas works well; and (4) Barriers to the Model School's Internal Quality Assurance System in SMPN 1 Sambas, among others, a complete and correct lack of understanding of teachers and education personnel on the Internal Quality Assurance System, the assumption that principals are responsible for guaranteeing, improving, and civilizing quality and funds inadequate. The conclusion obtained from this research is that the Internal Quality Assurance System at SMPN 1 Sambas has been running well even though there are some obstacles, but it can be handled well.
\end{abstract}

Keywords:Internal; Quality Assurance; System

\section{INTRODUCTION}

A quality education system must be built on solid principles with a clear paradigm, and must also be put in line with the demands and changes of the times. Law Number 20 of 2003 concerning the national education system states that education is carried out through a national education system, namely to develop capabilities and improve the quality of life and dignity of Indonesian people. The implication of the enactment of this law includes the need for an educational quality standard that is national in nature.

Among the efforts to determine education quality standards nationally is the existence of National Education Standards (Government Regulation Number 19 of 2005 concerning National Education Standards) for various types and levels of education units. In an effort to improve the quality of national education, on September 25, 2009, the government through the Minister of National Education issued a National Education Minister Regulation Number 63 of 2009 concerning the Education Quality Assurance System.
In this regulation, it is stated that "Educational quality assurance is a systemic and integrated activity by educational units or programs, organizers of units or educational programs, local governments, Governments, and communities to increase the intelligence level of the nation's life through education."

The Education Quality Assurance System hereinafter referred to as SPMP, is a "subsystem of the National Education System whose main function is to improve the quality of education." Every education unit and all its components have responsibilities in improving and quality assurance. Quality improvement in education units cannot run well without a quality culture in all components of the education unit. To improve the quality of schools as a whole, an approach that involves all components of the education unit is needed to have a quality culture jointly. Quality assurance can work well in all levels of education management by developing an education quality assurance system consisting of an Internal Quality Assurance System (SPMI) and an External Quality Assurance System (SPME). 
The Internal Quality Assurance System (SPMI) is a quality assurance system carried out by all components in an education unit that covers all aspects of the implementation of education by utilizing various resources to achieve the National Education Standards. The components of internal quality assurance are within the scope of the three main dimensions, namely inputs (input), process (process) and output (output), where each component has detailed subcomponents that describe the totality of the organization (program fund or educational unit), namely:

a. Input: identity, integrity, vision, mission, goals and objectives, students, educators, and education staff, curriculum, infrastructure and facilities, financing, governance, academic management, partnerships, information systems, quality assurance systems.

b. Process: learning process, learning content, and learning assessment.

c. Output: graduate.

The Internal Quality Assurance System is very important to be implemented so that quality fulfillment can be planned, implemented, and evaluated internally by the education unit. However, the implementation of guarantee and improvement in the quality of education is still facing various kinds of problems, among others: schools do not have the same perception of various aspects and indicators of assessment of the National Education Standards as a reference for quality education, implementation of guarantees and improvement in education quality are still limited to monitoring components quality in education units, quality mapping is still in the form of data collection on the achievement of education quality that has not been integrated from various education providers, and follow-up on the results of educational quality data that have not been utilized for the need for continuous quality improvement.

The education unit is expected to be able to implement the entire cycle in the quality assurance system independently and continuously so that the quality culture in the education unit can be formed. The quality assurance system that runs on the education unit and is carried out by all components in the education unit is referred to as SPMI. SPMI covers all aspects of implementing education by utilizing various resources to achieve SNP. This quality assurance system is evaluated and developed continuously by the education unit and also determined by the education unit to be included in the guidelines for managing the education unit and socialized to the education unit stakeholders. In order for the implementation of SPMI to be carried out by all educational units optimally, it is necessary to develop an education unit that will become a model for the implementation of independent education quality assurance, hereinafter referred to as model schools, as a direct illustration to other education units that will implement education quality assurance implementation of quality assurance to all education units in Indonesia.

In 2016 a model school program was carried out. Model school is a school based on national education standards, which includes 8 national education standards namely graduate competency standards, process standards, content standards, assessment standards, PTK standards, management standards, financing standards, facilities, and infrastructure standards.

The model school is a school that has been established and fostered by the Education Quality Assurance Agency (LPMP) to become a reference school for other schools around it in implementing independent education quality assurance. The model school applies the entire education quality assurance cycle in a systemic, holistic, and sustainable manner so that the quality culture grows and develops independently of the school.

The model school was selected from schools that did not meet the SNP to be fostered by LPMP together with local governments to be able to implement education quality assurance in their schools in an effort to meet the SNP. Coaching by LPMP and local government is carried out until the school has been able to carry out education quality assurance independently. Model schools serve as pilot schools for other schools that will implement education quality assurance independently. The model school has the responsibility to induce good practice in the implementation of education quality assurance to the five schools in the vicinity, the school that is being explained, hereinafter referred to as the impact school.

The model school will be fostered by LPMP assisted by district facilitators. Coaching received by the school in the form of training, mentoring, supervision and monitoring and evaluation. The training was carried out by LPMP until the school was able to carry out education quality assurance independently. School independence is measured by LPMP in monitoring and evaluation activities according to the instruments provided.

Model schools are schools that seek to implement the Internal Quality Assurance System (SPMI) model. Some education actors think that the model school is a great school, even though what is meant by the word "model" in the model school is the system that is the SPMI being modeled at the school.

Based on the above background, in Sambas sub-district, Sambas District, SMPN 1 Sambas has been used as a model school in the context of the internal education quality assurance system which will have the responsibility to counteract the practice of implementing education quality assurance to the five surrounding schools. So the researchers felt interested in researching and revealing the implementation of the model school's internal quality assurance system in SMPN 1 Sambas.

The reason researchers will conduct research at SMPN 1 Sambas is as follows:

a. Researchers want to know in depth about model schools.

b. The researcher wants to reveal the perceptions of the model school according to Principals, Teachers, School Committees, and Students of SMPN 1 Sambas.

c. Model school is a new program in the education quality assurance system.

d. No research has been conducted on the same problem at the school. 


\section{Methodology}

The adequacy of information from informants related to the focus of this research was determined based on the depth, depth and saturation of information obtained through interviews with informants. Until this research was completed and the researchers considered the data had met the adequacy according to the research objectives.

In interviews, the researcher will establish relationships with participants and conduct interviews regarding the activities for which the data is collected. The interview technique will be used to collect data in the form of words by asking questions to informants relating to the focus of the research. Questions are asked repeatedly until all information is revealed, and data is obtained through the informant's narrative according to the research objectives. The data or information that will be collected through interviews are matters related to the questions that have been determined in the focus of the research.

Observations that will be carried out at SMPN 1 Sambas in the form of collecting data in the form of action by looking at the daily activities at the location will be carried out on certain days, which are estimated to be December 2018 to March 2019. Activities that will be seen directly by researchers were the teaching and learning process, the activities of teachers and administrative staff, the activities of the principal, and student activities. Researchers do this activity while observing and recording what, how, and why the natural setting. Other results obtained from observations in the form of data on the physical and environmental conditions of the two schools studied.

To achieve the desired goal is carried out through steps; (a) identify the informant who fits the focus of the study, then determine the time and place, (b) prepare the interview in the form of introduction to the characteristics of the informant, outlines and the sequence of questions that refer to the research focus, (c) initiate interviews with general questions, (d) conduct core interviews with questions that lead to the topic of research, (e) stop the interview conducted by paying attention to several things, among others, if information is felt to be sufficient, or the situation is indeed not possible.

For the validity of the data obtained from the results of the interview, the researcher will conduct verification with the informant regarding the information provided by putting a signature on the interview note sheet. In this study, school documents used as a source of data in the form of data on the acquisition of student academic and non-academic achievements, quarterly report documents, and school program documents. The data collection techniques and tools are adjusted to the focus and purpose of the study.

The next step will be to systematically search and compile the data obtained from interviews, field notes, and documentation, by organizing data into categories, describing into units synthesizing, arranging into patterns, choosing which ones are important and which will studied, and made conclusions so that it is easily understood by researchers or other people (Sugiyono, 2016: 89).

The activities of collection and processing in this research are basically researchers doing together at the time of the data retrieval process considering the two things are interrelated and not separate (Sugiyono, 2016: 90). Activities in data analysis include:

a. Data Reduction. The amount of data obtained in the field is quite large, so it needs to be careful and detailed. Reducing data means: summarizing, choosing the main things, focusing on the important things, looking for themes and patterns, and removing unnecessary ones. Data that has been reduced will provide a clear picture and make it easier for researchers to carry out further data collection, and look for it if needed.

b. Presentation of data. After the data has been reduced, the next step is to display the data. Display data in qualitative research can be done in the form of brief descriptions, charts, relationships between categories, flowcharts, and so on. Miles and Huberman (1984) state: "the most frequent form of display data for qualitative research data in the past has been narrative text" meaning: the most frequently used to present data in qualitative research with narrative texts. In addition to being narrative, display data can also be in the form of graphs, matrices, networks (networks).

c. Verification (conclusion drawing / verification). The third step is drawing conclusions and verification. The initial conclusions put forward are still temporary and will change if no strong evidence is found to support the next stage of data collection. However, if conclusions have indeed been supported by valid and consistent evidence when the researcher returns to the field to collect data, then the conclusions put forward are credible conclusions.

Data obtained from various sources and informants will be sorted out and selected according to the group so that the analysis is easy and then grouped. The data to be grouped are then analyzed by interpreting or interpreting data that is appropriate and relevant to the focus of the study. Activities in qualitative research use data analysis and take place continuously until complete, so that the data is saturated (Sugiyono, 2016: 91).

In this research plan, data reduction conducted by researchers will simplify the data obtained from interview data. Thus the data that has been reduced will provide a clearer picture, and make it easier for researchers to carry out further data collection, search if needed, and the data is coded.

Data to be simplified will be coded and then presented in the form of data exposure. Then from the exposure of the data, some conclusions were taken, which were the findings of the study. Data or information obtained in the field is transcribed and arranged systematically and presented in descriptive verbal form. The quotations from the interviewer's findings present little in the data and overall data from the interview in the attachment to the report.

\section{Data Validity Check}

Researchers will do this by means of purposive sampling to ensure the reliability and accuracy of the data, namely selecting informants whose accuracy and relevance are 
appropriate between the data needed and the focus of the research.

For the validity of the data, the researcher will check the correctness of the data through source triangulation, technique, then the member checks until the data are saturated. The researcher will also conduct interviews and observations to test the truth of the data that will be obtained. In this case, the researcher triangulated data disclosure techniques.

When the researcher will compare and check back the degree of trust in information about matters related to the question in the focus of the study, the researcher conducted an interview related to the information with other resource persons. The researcher will draw conclusions then ask for an agreement (member check) to the informant earlier. In this case, the researcher conducted a triangulation with the data source.

Then the researcher will hold a triangulation of time that is testing the consistency of the data from the informant in order to obtain the credibility of the data that will be done more than once.

\section{Research stages}

This research is scheduled in three stages, namely preparation, implementation, and reporting. This is done in the hope that satisfying results can be obtained.

\section{RESULTS AND DISCUSSION}

\section{A. Results}

According to the exposure to the research data that has been described, the following will be presented in the research findings. The findings of this study are adjusted to the focus and research questions that have been developed, then the researchers present systematically into four parts. The four sections will be described by researchers in the third section below.

1. The input of the Model School Internal Quality Assurance System in SMPN 1 Sambas.

In implementing the School's Internal Quality Assurance System Model in SMPN 1 Sambas, inputs (inputs) have 16 (sixteen) components namely School Work Planning Program, Implementation of School Work Plans, Curriculum, Student Affairs, Finance, Inventory, Staffing, Intra-School Student Organizations (OSIS), Library, Principal As Supervisor, Public Relations, Laboratory. Complete Classes, School Committees, 7K, and Management Information Systems. Based on the recapitulation of managerial supervision by supervisors in 2018, all these components have been fulfilled by the Head of SMPN 1 Sambas with an average score of 84.34 from the maximum / perfect score of 100

2. The Process of the Model School Internal Quality Assurance System in SMPN 1 Sambas.

In the process of the Model School's Internal Quality Assurance System in SMPN 1 Sambas, data were found that the following matters; The school plans the learning process according to the provisions, the learning process is carried out correctly, Supervises the learning process activities, Authentic assessment is carried out in the learning process.

3. Output (Model) of the Model School's Internal Quality Assurance System in SMPN 1 Sambas

The Process of the School's Internal Quality Assurance System Model in SMPN 1 Sambas concerns the competencies of graduates of SMPN 1 Sambas, and Educational Units are able to run the entire internal quality assurance cycle and the functioning of the education quality assurance organization in SMPN 1 Sambas.

4. Obstacles to the Model School's Internal Quality Assurance System in SMPN 1 Sambas.

Barriers to the School's Internal Quality Assurance System Model in SMPN 1 Sambas, among others, are the tendency of teachers and education staff to lack an understanding of the Internal Education Quality Assurance System (SPMI) as a whole and correct, difficult to accept changes, and behave and opinion that responsibility for guaranteeing, improving, and civilizing quality lies only with the principal not at every individual in the school. Inadequate funding factors also influence the smooth implementation of the Model School's Internal Education Quality Assurance System program at SMPN 1 Sambas.

\section{B. Discussion}

1. Input (input) of the Model School Internal Quality Assurance System in SMPN 1 Sambas

In implementing the School's Internal Quality Assurance System Model in SMPN 1 Sambas, inputs have 16 (sixteen) components namely School Work Planning Program, Implementation of School Work Plans, Curriculum, Student Affairs, Finance, Inventory, Staffing, Intra-School Student Organizations (OSIS), Library, Principal As Supervisor, Public Relations, Laboratory. Complete Classes, School Committees, 7K, and Management Information Systems. Based on the recapitulation of the results of managerial supervision of supervisor supervisors in 2018, all these components have been met by the Head of SMPN 1 Sambas with an average score of 84.34 from the maximum / perfect value of 100

In 2016 SMPN 1 Sambas and Keramat Teluk 2 Middle School were proposed by the Education and Culture Office of Sambas Regency to West Kalimantan LPMP to become a Model School in Sambas District. The proposal was approved by the West Kalimantan LPMP.

From 2016 to 2018 as a model school, SMPN 1 Sambas received various training from LPMP and received assistance from the Regional Facilitator (FASDA) in developing quality with the Internal Education Quality Assurance System, the basis of which was the School Quality Report Card the previous year.

It was recognized that SMPN 1 Sambas had facilities and infrastructure in accordance with the National Education Standards. The results of the observations conducted by the Researchers at SMPN 1 Sambas were adequate and adequate 
facilities and infrastructure for learning activities and were very supportive for the implementation of the Model School's Internal Education Quality Assurance System. The environment is clean, well organized, ornamental plants and medicinal plants meet every corner of the yard. Very beautiful, comfortable, and comfortable in that location. This means that from the ownership of facilities and infrastructure of SMPN 1 Sambas, they have no difficulty in implementing the Model School's Internal Education Quality Assurance System.

The standard of facilities and infrastructure owned must certainly be in accordance with the quality data of the Education Unit results of the quality report of SMPN 1 Sambas in 2018. The achievement of standard facilities and infrastructure for the quality of the SMPN 1 Sambas in 2018 is 4.363 star categories. The details of the indicators and sub-indicators are as follows;

"The capacity to accommodate the school is adequate; its value is 4.59 in the 3 -star category. This means that this component indicator of SMPN 1 Sambas is headed for SNP 3. For school SNPs, it must be able to reach a 5-star value, and the value for SNP is 7 stars. The capacity of the school's sub-indicators is as follows ; Having the capacity of an appropriate study group and adequate values of 0 stars 1 . The ratio of the land area according to the number of students of 7 stars 5. The ratio of building area according to the number of students is 3.5 stars 2. School land conditions meet the requirements of a 7 -star 4 . The condition of school buildings meets the requirements of the value of 6.12 stars 4 . Has a variety of infrastructure in accordance with the provisions of the value of 2.152 stars.

Schools have complete and feasible learning facilities and infrastructure with a value of 4.463 star categories. For SNP schools must be able to reach the value of 75 star categories. The school sub-institution has complete and decent learning facilities and infrastructure, namely having classrooms according to the standard value of 6.21 star 4 . Have a science laboratory according to the standard value of 4.66 stars 3 . Has a library space according to the 4.55 star 3 standards. Have a playground / field according to the standard value of 0 stars 1 . The condition of the classroom is feasible to use the value of 5.624 stars. The laboratory conditions of the IPA are worth the value of 4.663 stars (library). The condition of the library space is worth using a value of 1 star for the 5-star category.

The school has supporting facilities and infrastructure that are complete and worthy of the value of 2.422 stars. For SNPs, the school must be able to reach a 5-star value. The school sub-institution has complete and feasible supporting facilities and infrastructure, namely having a leadership room according to the standard value of 2.64 stars 2 . It has a teacher's room according to the standard value of 0 stars, UKS space according to the standard 3.06 star 2, a place of worship according to the standard value of 1 star, a toilet according to the standard value of 3.32 stars 2 , a warehouse according to the standard value of 0 stars 1 , a circulation space according to the standard value of 0 stars 1 , administrative room according to the standard value of 0.1 , a counseling room according to the standard value of 0 stars 1 , a student organization room according to the standard value of 0 stars. It also provides a decent canteen a value of 7 stars 5 and an adequate parking space with a value of 6.995 stars. The Condition of the leadership room is worth using a value of 0 stars 1 . Condition of the teacher's room is worth using a value of 0 stars 1 . Personal conditions the UKS is worth using a value of 5.64 stars. Condition of a place of worship is worth using a value of 3.5 stars 2 . Latrine conditions are in accordance with the standard value of 4.663 stars and 5 stars. Condition of the administrative room is worth using a value of 1.4 stars 1 . Condition of the counseling room is worth using a value of 1 star. Condition of student organization room is worth 2.33 stars 2. (Source: Achievement of Quality Report Card for Sambas 1 Public High School in 2018)

From the report card quality components and infrastructure components of SMPN 1 Sambas in 2018, it can be seen that there are sub-components that need to be addressed whose value is under the 4-star category. There is a contradiction between the results of observations of Public Middle School facilities and infrastructure with the results of report card quality and infrastructure component quality at SMPN 1 Sambas in 2018.

These differences, among others, according to the results of the Researcher's observations of the facilities and infrastructure of SMPN 1 Sambas school sub-indicators have the appropriate and adequate capacity of study groups, which is 32 maxims according to SPM, but the PMP SMPN 1 Sambas report card shows that the school has the capacity of study groups according to an adequate value of 0 stars 1 . According to the results of observation of the researcher the condition of the library space is feasible, clean, neatly arranged and the documents are complete, and the books are adequate, but the data are shown by the achievement of the 2018 SMPN 1 Sambas report card shows the condition of the library space is worth using a value of 0 stars 1 .

Likewise with other sub-indicators such as places of worship, circulation rooms, administrative space, counseling rooms, student organization space, conditions of leadership rooms, and conditions of the teacher's room all achievements according to the 2018 SMPN 1 Sambas report card data show a value of 1-star category. According to the Researcher's observations that all the sub-indicators of the room have good and proper conditions to support the implementation of Internal Quality Assurance System in the model school (SMPN 1 Sambas).

The difference between the results of the observations Researchers with data on the results of the PMP report at SMPN 1 Sambas in 2018 after being confirmed by the head of SMPN 1 Sambas, School teachers and operators there are bright points. The problem is in the differences in viewpoints in assessing the relevant sub-indicators. The researcher looked at the sub-indicator from the point of view of the existence when the researcher was in the location of the research while the data was mostly carried out by the operator as the impostor of the data of PMP SMPN 1 Sambas. 
This difference was also triggered by the different perceptions in understanding the PMP instrument for those who were given the task by the school to fill in the PMP instruments prepared by LPMP. PMP instruments that are given a number of questions are quite a lot, which is around 581 questions that must be filled by the principal, teacher representatives of at least 8-10 teachers, student representatives of at least 15 students per school, at least 1 representative of the committee leader, at least 2 parents and supervisor supervisors SMPN 1 Sambas. The types of questions in the instrument are the same and there are questions in the instrument that concern students and teachers which in fact the situation and conditions are only known by the teacher and headmaster but the questions in the instrument also apply to committee representatives, parents' representatives and supervisors who do not rule out know exactly the conditions asked.

Furthermore, from the findings of the input research (input) the School Internal Quality Assurance System Model in SMPN 1 Sambas, there are 16 (sixteen) components that have been met by the Head of SMPN 1 Sambas with an average score of 84.34 from the maximum / perfect value of 100 .

The data obtained from the results of managerial supervision of supervisors supervisor of SMPN 1 Sambas in 2018. Data from the managerial supervision of supervisors of the SMPN 1 Sambas 2018 states that;

"School Work Planning Program scores 97.22, Implementation of School Work Plans values 90.91, Curriculum scores 86.36, Student grades 76.04, Finance scores 91.07, Inventory values 75.00, Staffing scores 79.41, Student grades 80.00, Library values 89.06, Principals as Academic Supervisors value 80.00, Public Relations value 72.50, Laboratory value 77.27, Class Completion value 90.63, School Committee score 77.27, $7 \mathrm{~K}$ value 95.00, Management Information System value 91.67 value Average Score 84.34 (Source: Managerial Supervision Instrument for Supervisors of SMPN 1 Sambas in 2018).

Based on data from the Managerial Supervision Supervisory Instrument of SMPN 1 Sambas in 2018 and narrative from the head of SMPN 1 Sambas there was a tendency for input The School's Internal Education Quality Assurance System Model in SMPN 1 Sambas was suitable and very adequate not only as a model school but increased to a referral school.

In SMPN 1 Sambas, the input factors of the Model School Internal Education Quality Assurance System are well managed and all cooperative stockholders. If this condition can be created, it does not rule out the possibility of making SMPN 1 Sambas a culturally quality school that will become a reality. The steps were taken by principals to improve school quality in SMPN 1 Sambas by implementing participatory and cooperative management in managing input factors of the Internal Education Quality Assurance System be a must. In order for the program to be effective, it must be supported by teachers, employees, parents, school committees, and other stockholders and adjusted to the real conditions in SMPN 1 Sambas.
In line with the above opinion in Document 04.4 School Development Models and Patterns for Induction (2016: 10) said that the implementation of education quality assurance requires the involvement of all school components. Coaching will be carried out with a participatory approach involving all components of school stakeholders, namely school supervisors, principals, teachers, education staff, school committees, parents, and students. Schools will be fostered to involve stakeholders outside the school, such as village heads, companies, NGOs, and others.

\section{The Process of the Model School Internal Quality} Assurance System in SMPN 1 Sambas

In the process of the Model School's Internal Quality Assurance System in SMPN 1 Sambas, the school plans the learning process according to the provisions, the learning process is carried out appropriately, Supervises the learning process activities, Authentic assessment is carried out in the learning process.

The planning of the learning process by each teacher at SMPN 1 Sambas is outlined in the Learning Implementation Plan (RPP). Every year, the Learning Implementation Plan (RPP) should be revised and developed in accordance with applicable regulations and current. Or updated

Udin Syaefudin Sa'ud and Abin Syamsudin Makmun (2009: 33) states that planning is seen as important and necessary for an organization, among others: (a) it is expected that the growth of direction and the guidance for the implementation of activities aimed at achieving goals, (b ) with the planning, an estimate (forecasting) can be carried out on things during the implementation period, (c) planning provides an opportunity to choose various alternatives on the best alternative or the opportunity to choose the best combination (the best combination), (d) with planning for prioritizing, and (e) with planning, there will be a measuring device or standard for conducting monitoring or performance evaluation.

Mulyono (2008: 25-26) says that planning means: first, managers think carefully about the target (goal) and action based on several methods, plans, or logic and not based on feelings. Second, plan to aim at the organization and establish the best procedures for achieving it. Third, the plan is a guideline for (a) the organization obtains and uses the resources needed to achieve the objectives, (b) the members of the organization carry out activities that are consistent with the stated objectives and procedures, and (c) monitor and measure progress to achieve goals so that corrective action can be taken if progress is not satisfactory.

The planning of the learning process in the School Internal Quality Assurance System Model in SMPN 1 Sambas by the principal and the teacher contains elements, principles and planning steps in accordance with Mulyono's opinion (2008: 25-26) and in line with Syaefudin Sa'ud and Abin Syamsudin Makmun's view (2009: 33) about the importance of making a plan as a process to follow up on a policy that is both vertical and horizontal.

The implementation of the learning process is carried out appropriately according to the time allocation and planning 
that has been made and the applicable curriculum, namely the curriculum 2013. Lessons and time allocations for the curriculum of the SMPN 1 Sambas are guided by the Curriculum Structure listed in the Standard Content. Subjects consist of general group A subjects and group B general subjects. Learning loads are all activities that students must follow in one week, one semester, and one learning year of at least 38 lesson hours, one semester at least 18 weeks effective. The data in document I of SMPN 1 Sambas must be the attention of the teacher in planning learning.

The implementation of the learning process is carried out precisely according to the schedule prepared by the curriculum section. The arrangement of the schedule usually takes into account the educational calendar that has been prepared by the Education and Culture Office of Sambas Regency and adjusted to the conditions of the school, environment, and local culture. This means that there is an agreement between various parties in the implementation of the learning process.

In line with the description above, Fathurrohman and Sutikno (2010: 10) state that, the teaching and learning process is a series of activities agreed upon and carried out by the teacher-student to achieve educational goals optimally.

Furthermore, Fathurrohman and Sutikno (2010: 111) state that the ability to manage a good teaching and learning process will create a situation that allows children to learn, so that is the starting point for the success of teaching. Students can learn in a reasonable atmosphere, without pressure and in conditions that stimulate learning.

There is a similarity between the concept of the implementation of the learning process carried out by SMPN 1 Sambas with the opinions of the two experts above.

Supervision of the learning process activities is carried out by the Principal as an Academic Supervisor. The principal supervises the teacher as a coaching effort through the provision of services and assistance which is directed and encourages the teacher to develop and improve themselves so that they can improve their abilities, managing their main tasks in managing learning, so that the learning process is more qualified.

According to Muslim (2009: 37), supervision is more likely to service efforts and provide assistance in order to advance and improve the process and results of teaching and learning. In essence, supervision is an improvement in terms of learning and teaching by conducting stimulation, coordination, and guidance continuously to improve the growth of individual and group teacher positions (Sagala: 2010.92).

Furthermore, Herabudin (2009: 196) said that supervision is the guidance given to all school staff so that they can improve their ability to develop better teaching and learning situations. Substantially, the meaning of supervision contains elements; goals, teaching and learning situations, supervision, guidance and direction, critical assessment, and supervising duties.

Related to the supervision of the learning process activities carried out by the Principal as an Academic Supervisor has a tendency to mean the same as what is said by Muslim (2009: 37), Sagala (2010: 92) and Herabudin (2009: 196)

An authentic assessment carried out in the learning process is competency-based assessment, that is, part of the learning activities carried out to find out the achievements of student competencies, which include knowledge, skills, and attitudes.

Assessment is carried out during the learning process and / or at the end of learning. The focus of educational assessment is the success of student learning in achieving specified competency standards. At the subject level, competencies that must be achieved in the form of Competency Standards (SK) for the next subject are described in Basic Competencies (KD). For the education unit level, the competencies that must be achieved by students are the Graduate Competency Standards (SKL).

Assessment of learning outcomes students must pay attention to the principles as follows valid, objective, fair, integrated, open, comprehensive and continuous, systematic, and accountable, namely the assessment can be accounted for, both in terms of techniques, procedures, and results.

Various types of valuation techniques can be done complementary in accordance with the competencies assessed. The assessment techniques referred to include, among others, tests, observation, assignments, inventory, journals, self-assessments, and interpersonal assessments that are in accordance with the characteristics of competencies and the level of student development.

Reference Criteria for assessment are based on measures of achievement of specified competencies, for example, minimal learning completeness (KKM) determined by the education unit by considering the characteristics of the Basic competencies to be achieved, the carrying capacity (means and teachers), and characteristics of students. increase in minimum completeness criteria (KKM) to achieve the expected ideal completeness criteria.

In line with the concept of authentic assessment conducted at SMPN 1 Sambas above, Majid (2008: 186-187) states that authentic assessment is the process of collecting information by teachers about the development and achievement of students' learning through various techniques that are able to express, prove or show precisely that the learning objectives and abilities (competencies) have been truly mastered and achieved.

Continued by Majid (2008: 187) that authentic assessment of the principles is as follows: first the assessment process must be an integral part of the learning process; both assessments must reflect real-world problems, not the problems of the school world; all three assessments must use various sizes, methods, and criteria that are in accordance with the characteristics and essence of the learning experience; and all four assessments must be holistic, covering all aspects of learning objectives (cognitive, affective and sensory-motor).

Looking at the explanation of authentic assessment according to the informant's narrative in SMPN 1 Sambas there is a tendency to show its orientation as the explanation of authentic assessment according to Majid (2008: 186-187). 
3. Output (Model) of the Model School's Internal Quality Assurance System in SMPN 1 Sambas

The Process of the School's Internal Quality Assurance System Model in SMPN 1 Sambas concerns the competencies of graduates of SMPN 1 Sambas. The education unit is able to run the entire cycle of internal quality assurance and the functioning of the education quality assurance organization in SMPN 1 Sambas.

Regarding the competencies of graduates of SMPN 1 Sambas as the findings above are in accordance with Jenkins' opinion in (Widodo, 2011: 13) saying "Schools that have good criteria are schools that are able to produce fewer graduates who are not ready, few do not graduate, and many graduates continue their education to a higher chosen level. "

If the data provided by SMPN 1 Sambas in filling out the PMP instrument in 2018 and the results in the form of Quality Report Card for the SMPN 1 Sambas in 2018 which came out early in 2019 it is valid then quality in fact (Actual quality) and quality in perception (Quality according to perception) will be fulfilled as according to Sallis (2010.7) who said that in the implementation of quality in fact is the profile of graduates of educational institutions that are in accordance with the qualifications of educational goals, in the form of basic ability standards in the form of minimal academic qualifications controlled by students while quality in perception education is satisfaction and the increasing interest of external customers towards graduates of educational institutions.

Moving on from these factors by the principal is still felt to be less optimal in its implementation, it is good that Sallis's opinion (2010.7-10) is made into consideration, namely; first continuous improvement, second determine quality standards, third culture change (change of culture), fourth organizational change (upside-down organization), and fifth maintain customer relations (keeping close to the customer )

Related to the factors that affect school quality, Widodo (2011: 12) said that the quality of graduates could not be separated from a cycle flow starting from contact, Input, Process, Output, and Outcome. For this reason, Widodo said that the quality of graduates who are in accordance with the wishes of the education customers is the output that has the criteria as outgoing, that is, can continue to higher school and can prepare students to continue to higher levels and work.

With regard to the quality of graduates as meant by the quality of graduates according to the Model School's Internal Quality Assurance System in SMPN 1 Sambas, the school has not been able to fully realize the concept of school quality as expressed by the principal. Even though this school has the power of having 8 SNP fulfillment performance, most of them have fulfilled the SNP and accreditation results A.

Based on the findings above, if it is associated with the results achieved by the school in graduating students, it means that the teacher has not been able to provide services fully. This is evidenced by the acquisition of graduations that are still unable to reach the top 5 scores at district level examinations. Whereas the strategic position of teachers to improve the quality of education outcomes is strongly influenced by competence and quality of performance, and in general, the quality of good education is a benchmark for the success of the performance shown by the teacher.

As stated by Mulyasa (2009.5) that teachers are the most decisive component to improve the quality of education. Because in the hands of teachers, the curriculum, learning resources, facilities and infrastructure, and the learning climate become meaningful to the lives of students.

In line with the quality of the school graduates above, Kosasih (2010: 16) said that "quality schools are schools whose conditions or conditions have characteristics that match the ideal demands and expectations of the principal, teachers, employees, students, parents, funders, and users school graduate." In order for these ideal demands and expectations to be realized, there are several requirements that must be fulfilled by the school to go in that direction, as said by Sukmadinata (2010: 9-11).

a. Improving the quality of education demands professional leadership in the field of education.

b. The difficulty faced by leadership professionals is their inability to deal with "system failure" that prevents them from developing or implementing new methods or processes to improve the quality of existing education.

c. Improving the quality of education must make leaps and bounds that are able to compete in the global world.

d. Money is not the main key in efforts to improve quality.

e. The main key to improving quality is a commitment to change.

f. Many education professionals lack the knowledge and expertise to prepare students to enter the global labor market. Fear of change or fear of making changes will result in ignorance of how to deal with new demands.

g. Quality improvement programs in the commercial field cannot be used directly in the field of education, but require adjustments and improvements.

h. One key component in a quality program is a measurement system.

i. Communities and management of education must distance themselves from the habit of using "short programs" because quality improvement can be achieved through sustainable change, not with short programs.

Thus the concept of quality of school graduates as stated above if implemented as intended by speakers will certainly produce quality education as stated by Mulyasa (2009.5) that teachers are the most decisive component to improve the quality of education. Because in the hands of teachers, the curriculum, learning resources, facilities and infrastructure, and the learning climate become meaningful to the lives of students.

Regarding the education unit capable of carrying out the entire cycle of international quality assurance as to the findings above was in line with the basic concept of model school. Model schools are schools that are established and nurtured by the Education Quality Assurance Agency (LPMP) to become a reference school for other schools in the vicinity in the implementation of independent education quality assurance. The model school applies the entire 
education cycle in a systematic, holistic, and sustainable manner, so the quality culture grows and developing independently in the school. The model school is used as a pilot school for other schools that will implement education quality assurance independently.

Furthermore, according to Document 02 General Guidelines for Primary and Secondary Education Quality Assurance System (Dirjendikdasmen, 2016: 15-16) that the Primary and Secondary Education Quality Assurance System is an integrated unit consisting of organizations, policies, and integrated processes that regulate all activities to improve quality Primary and Secondary Education in a systematic, planned and sustainable manner. The aim is to ensure compliance with basic and secondary education units systemically, holistically, and sustainably, so as to grow and develop a quality culture in independent education units.

In its implementation, primary and secondary education quality assurance systems follow the activity cycle in accordance with their respective components. The internal quality assurance system cycle consists of first mapping the quality of education carried out by educational units based on the National Education Standards; the second plan for increasing the amount outlined in the School Work Plan; the third is the implementation of quality fulfillment both in the management of the education unit and the learning process; fourth, monitoring and evaluating the process of implementing quality fulfillment that has been carried out; and fifth, setting new standards and developing quality improvement strategies based on the results of monitoring and evaluation.

There are conformity trends between the opinions of informants and the opinions of experts as the researchers quoted in document 02 of the General Guidelines for Primary and Secondary Education Quality Assurance Systems (Dirjendikdasmen, 2016: 15-16) about the education quality assurance cycle applied in the Model School Internal Quality Assurance System Process in Middle School Negeri 1 Sambas.

Next is the discussion about the functioning of the educational quality assurance organization in SMPN 1 Sambas. The existing teacher has academic feasibility to carry out the learning process in the Model School Internal Quality Assurance System Process in SMPN 1 Sambas. The demands of the development of time require a teacher to be professional. To become professional teachers are required to meet the minimum academic quality (minimum junior high school teacher) and certified educators. These teachers who meet the professional criteria are expected to be able to carry out education and learning to achieve national education goals, able to carry out the functions of the educational quality assurance organization in SMPN 1 Sambas.

This quality human resource if managed properly is a force that can be utilized to achieve the vision, mission, and goals planned by the school. It all depends on whether or not the organization is in school. If the organization in the school is running and functioning properly, the planned education goals will be easy to achieve. Conversely, if the existing organization does not run and function properly, it will disrupt the process of achieving the objectives planned by the school.

As stated in the Document 03 Educational Quality Assurance by the Education Unit (Dirjendikdasmen, 2016: 16-17) stated that the quality assurance system could run well in the education unit if there are elements of quality assurance in its management. The elements of quality assurance can be in the form of the School Education Quality Assurance Team (TPMPS) which is an independent team outside of school management that contains at least representatives of the leadership of the education unit, educators, and other education personnel and committees in the education unit.

If the resources of the education unit are insufficient, the quality assurance function is the task of the management team that already exists in the education unit. The education unit in carrying out tasks in the education quality assurance system can coordinate and cooperate with the Regional Education Quality Assurance Team (TPMPD) formed by the regional government.

Further stated in the Document 03 Educational Quality Assurance by the Education Unit (Dirjendikdasmen, 2016: 18-19) that the measure of the success of quality assurance by the education unit consists of;

a. Process indicators, namely the increase in the capacity of the education unit in carrying out the closed education guarantee cycle that can be identified from the change in management of the education unit, the existence of policies and implementation of policies that refer to the SNP; increased ability to plan and implement quality management plans prepared; and increased ability to monitor and evaluate the mechanisms that have been carried out.

b. Output indicators, namely the realization of improving the quality of education in the education unit, which is indicated by the increasing competence of educators in carrying out the learning process ranging from planning to assessment, development of extracurricular activities, improvement of infrastructure and financial management, cooperation and involvement of all stakeholders.

c. Outcome indicators; an increase in student learning outcomes; competency test and performance assessment of educators and education authorities; educational unit achievements along with members; the realization of a pleasant learning environment; an award and financial support from stakeholders.

d. Impact indicators; namely the establishment of a quality culture with the implementation of quality assurance that is continuous and sustainable in the education unit.

Furthermore, stated in the Education Unit Quality Document 03 Quality Assurance (Dirjendikdasmen, 2016: 19-20) that the successful implementation of quality assurance in education units is influenced by:

a. Central government support in the form of national policies that regulate the national education guarantee system. 
b. Local government support in the form of policies that regulate the education quality assurance system in the area where it is responsible for.

c. The policy of the education unit that is manifested in the vision, mission, strategy, and program in carrying out the management of education and learning units in accordance with the educational reference.

d. The leadership of an effective education unit.

e. Participation, commitment, and consistency of all stakeholders in supporting guarantees and improving the quality of education units.

f. Accountability, transparency, and integrity that are the organizational culture (educational units, government, and other stakeholders involved in administering education).

Related to this, Mulyasa (2009.5) said, "Teachers are the most influential component in creating quality education processes and outcomes. Therefore, any efforts to improve the quality of education will not contribute significantly without being supported by professional and quality teachers. Improving the quality of education must originate from the teacher and lead to the teacher as well".

4. Obstacles to the Model School's Internal Quality Assurance System in SMPN 1 Sambas

Barriers to the Model School's Internal Quality Assurance System in SMPN 1 Sambas include the tendency of teachers and education staff to lack an understanding of the Internal Education Quality Assurance System (SPMI) as a whole and correctly, it is difficult to accept changes, and the attitude and opinion to guarantee, improving, and cultivating quality lies only with the principal rather than for every individual in the school. Inadequate funding factors also influence the smooth implementation of the Model School Internal Quality Assurance System program at SMPN 1 Sambas.

In implementing a policy or program, it is possible that there will be obstacles that will hinder its implementation. Likewise, the implementation of the Model School Internal Quality Assurance System in SMPN 1 Sambas.

The Head of SMPN 1 Sambas said that during the SMPN 1 Sambas was designated as a model school, the implementation of the Internal Quality Assurance System did have obstacles, for example, the limited number and competence of human resources who understood the internal quality assurance system (SPMI) in its entirety, thus reducing involvement in the process of implementing internal quality assurance in schools. This is because most of the teachers in SMPN 1 Sambas are approaching retirement (01/InSPMI/W-KS/2019)

The Principal as the leader of SMPN 1 Sambas formed a solid, loyal and committed work team starting from preparing the design, preparation and implementation of the Model School Internal Quality Assurance System at SMPN 1 Sambas. When the SPMI model school team started working on policy formulation, the strategy and the standards should refer to the Model School Internal Quality Assurance System documents that have been issued by the Directorate General of Primary and Secondary Education of the Ministry of Education and Culture.

The cooperation of all elements of stakeholders, both internal and external, must support real and full in the context of the successful implementation of the Model School Internal Quality Assurance System in SMPN 1 Sambas.

For all devices or work units and all human resources of SMPN 1 Sambas which consistently, loyally and committedly implement and implement the School's Internal Quality Assurance System Model in SMPN 1 Sambas in daily routine activities a reward and punishment system is provided in order to stimulate and giving enthusiasm in implementing the Model School Internal Quality Assurance System in SMPN 1 Sambas. The hope is that they become more motivated.

\section{CONCLUSIONS AND SUGGESTIONS}

\section{A. Conclusions}

After discussion of the research can be concluded several conclusions as follows;

1. In implementing the School's Internal Quality Assurance System Model in SMPN 1 SAMBAS, the input (input) has 16 (sixteen) components.

2. In the process of the School's Internal Quality Assurance System, SMPN 1 SAMBAS has gone through the stages of planning, implementation, and supervision in accordance with the provisions and carried out appropriately.

3. The output of the School's Internal Quality Assurance System Model in SMPN 1 SAMBAS which includes the competencies of graduates of SMPN 1 Sambas, the ability of schools to carry out the entire cycle of internal quality assurance and educational quality assurance organizations in SMPN 1 Sambas to function well.

4. Obstacles to the School's Internal Quality Assurance System The model in SMPN 1 Sambas felt by the school includes the tendency of some teachers and education staff to lack an understanding of the Internal Quality Assurance System (SPMI) as a whole and correctly, as well as the attitude and responsibility for guaranteeing, improving, and civilizing quality lies only with the principal not at every individual in the school. Inadequate funding factors also influence the smooth implementation of the Model School Internal Quality Assurance System program at SMPN 1 Sambas.

\section{B. Suggestions}

From the conclusions that the researchers have stated above, there are several suggestions that the researchers convey, namely;

1. Specifically, this suggestion is directed to SMPN 1 Sambas 1 that the School's Internal Quality Assurance System Model in SMPN 1 Sambas is very much determined by the collaboration of all components and human resources both in SMPN 1 Sambas and related institutions both vertically and horizontally, then it is recommended: 
2. To those who make policies related to teacher development through training, upgrading, MGMP, MKKS, workshops, or seminars so that the Internal Education Quality Assurance System material will also receive a portion in training.

3. To the principal, so that participatory and cooperative management has been implemented so that it is intensified, especially in establishing harmonious relations with parents of students by empowering public relations and school committee members.

4. To the teacher and TU that the Internal Quality Assurance System should not be assessed as if the burden of carrying out the task either as an educator or as an educational staff, but it is better to place the condition as our additional charity in providing educational services to students. Hopefully, with this action, the quality culture becomes something we usually carry out wherever and whenever.

\section{REFERENCES}

Direktorat Jenderal Pendidikan Dasar dan Menengah (Dirjendikdasmen). (2016). Pedoman Umum "Sistem Penjaminan Mutu Pendidikan Dasar dan Menengah" (Dokumen 02). Jakarta: Kementerian Pendidikan dan Kebudayaan.

Direktorat Jenderal Pendidikan Dasar dan Menengah (Dirjendikdasmen). (2016). Petunjuk Pelaksanaan "Penjaminan Mutu Pendidikan oleh Satuan Pendidikan". (Dokumen 03). Jakarta: Kementerian Pendidikan dan Kebudayaan.

Fathurrohman, P. \& Sutikno, M S. (2010). Strategi Belajar Mengajar. Melalui Penanaman Konsep Umum dan Konsep Islami. Bandung: PT.Rafika Aditama.

Herabudin. (2009). Administrasi dan Supervisi Pendidikan. Bandung: CV.Pustaka Setia.

Kosasih, Engkos. (2010). Implementasi manajemen Strategis. Di Tingkat Satuan Pendidikan Menengah. Bandung: PT Setia Purna invest.

Majid, A. (2008). Perencanaan Pembelajaran Mengembangkan. Standar Kompetensi Guru. Bandung: PT. Remaja Rosda karya.

Mulyasa. (2009). Praktik Penelitian Tindakan Kelas. Bandung: Rosda Karya.

Mulyono. (2008). Manajemen Administrasi \& Organisasi Pendidikan. Yogjakarta: Ar-Ruzz Media.

Muslim, Sri Banun. (2009). Supervisi Pendidikan Meningkatkan Kualitas Profesionalisme Guru. Bandung: Alfabeta.

Peraturan Menteri Pendidikan Nasional Nomor 63 Tahun 2009 tentang Sistem Penjaminan Mutu Pendidikan.

Peraturan Pemerintah Nomor 19 tahun 2005 tentang Standar Nasional Pendidikan.

Sagala, S. (2010). Supervisi Pembelajaran dalam Profesi Pendidikan. Bandung:Alfa Beta.

Sallis, Edward. (2011). Total Quality management in Education. Mutu Manajemen Pendidikan. Transleted by: Riadi.A.A \& Fahrurrozi. Jogjakarta: IRCiSoD.
Sugiyono. (2016). Metode Penelitian Pendidikan. Pendekatan Kuantitatif, Kualitatif dan $R \& D$. Bandung: CV.Alfabeta.

Sukmadinata N,S. (2010). Metode Penelitian Pendidikan. Bandung: PT.Remaja Rosdakarya.

Undang-Undang Republik Indonesia Nomor 20 Tahun 2003 tentang Sistem Pendidikan Nasional (Lembaran Negara Tahun 2003 Nomor 78 Tambahan Lembaran Negara Nomor 4301).

Widodo, E.S. (2011). Manajemen Mutu Pendidikan: Untuk Guru dan Kepala Sekolah. Jakarta: PT. Ardadizya Jaya. 